\title{
EXAMINATION OF THE CENTRAL VISUAL FIELD AT A READING DISTANCE*†
}

\author{
BY \\ V. N. HIGHMAN \\ Moorfields Eye Hospital, City Road, London
}

THIS investigation was started in an attempt to produce a simple, self-recording method of examining the central visual field that is readily performed at a reading distance, for example at the bedside or desk. A specially-designed chart incorporating a grid system, a pen, and a good light are the only necessary items of equipment. The use of a grid is based on the chart described by Amsler (1953) for the detection of early disturbances within the macular area which appear as a distortion of vertical or horizontal lines. The area covered by the Amsler Chart is a square subtending an angle of $20^{\circ}, 10^{\circ}$ to the right, to the left, above, and below the fixation point, when held $30 \mathrm{~cm}$. from the eye. Small as this area is, scotomata near the macula may be apparent. It was felt that this form of static perimetry could be modified for the plotting of central visual field defects. The following factors were taken into consideration whilst designing the chart.

\section{(1) Size and Shape of Chart}

In order to carry out an adequate examination of the central visual field, the blind spot area must be included, so that the chart must subtend an angle of at least $40^{\circ}, 20^{\circ}$ on each side of the fixation point. A square border, as in the Amsler Chart, is unsatisfactory owing to the subjective blurring of the corners. A circle with a radius of $10 \mathrm{~cm}$., which subtends an angle of $40^{\circ}$ when held $30 \mathrm{~cm}$. from the eye, also proves unsatisfactory because of the subjective blurring which may occur in the region of 2 and 8 o'clock on the circular border, or at 4 and 10 o'clock, or at all four positions. Finally an ellipse was constructed which minimizes the subjective border blurring and has the further advantage of coinciding more nearly with the shape of isopters of different targets.

\section{(2) Distance of Chart from Eye}

A distance of $30 \mathrm{~cm}$. from the chart to the eye is the most convenient because it does not require a chart which is too large and cumbersome. It is also the distance used in the Goldmann Projection Perimeter, thus permitting the two methods to be readily compared.

\section{(3) Size of Grid}

The size of the grid must be such that small or early scotomata are demonstrable. Sectional graph paper, which is available in a great variety of sizes, has the disadvantage of being composed of two or three different thicknesses of lines, which may cause some confusion whilst instructing the patient or during the plotting of the field. It is possible to plot field defects with $2 \mathrm{~mm} ., 1 \mathrm{~cm}$., and $2 \mathrm{~cm}$. sectional graph paper, but a quadrille ruling (the printer's description) which has no bold lines is the most satisfactory; the size used being "tenths quadrille" (the metric sizes are not available).

* Received for publication April 21, 1967.

+ Address for reprints: as above. 


\section{(4) Fixation, the Blind Spot, and Co-operation}

To demonstrate the blind spot subjectively using a grid is practically impossible. However, the blind spot may be subjectively found in the time-honoured method, using a small disc for fixation and a larger one, temporal to the fixation disc, which disappears when it lies within the area of the blind spot. Williamson-Noble made use of the same method in his Scotoma Detector (1953). It is only when the patient is co-operating and fixing properly that it is possible to demonstrate the blind spot, thus solving all three problems together.

\section{Method}

The chart was constructed as follows: the elliptical border, major axis $22 \mathrm{~cm}$. (subtending an angle of $44^{\circ}$ at $30 \mathrm{~cm}$.) in the horizontal meridian; and the minor axis $16 \mathrm{~cm}$. (subtending an angle of $32^{\circ}$ ) in the vertical meridian. In order to produce a sharp contrast between the elliptical border and the grid, the ellipse was cut out of matt black paper and placed over the grid (Fig. 1). The patient was asked to fix on a red disc $5 \mathrm{~mm}$. in diameter, placed at the junction of the horizontal and vertical meridians. The blind-spot finder was a black disc $8 \mathrm{~mm}$. in diameter, this being the most suitable size and shape and lying well within the elliptical border. The blind spot is centred approximately $15^{\circ}$ temporal to fixation; on the chart this distance is $7.5 \mathrm{~cm}$., so that when the blind-spot finder is lost the chart is automatically located at about $30 \mathrm{~cm}$. from the eye. The grid was in tenths quadrille (lines ruled at $0 \cdot 1^{\prime \prime}$ intervals), the ruling being in grey on a cream wove paper. Illumination was from a 150 watt filter lamp positioned to give $1000 \mathrm{asb}$. In practice this distance is about $60 \mathrm{~cm}$. from the chart.

FIG. 1.-The chart as presented to the right eye of the patient; this may be turned round when used for the other eye.

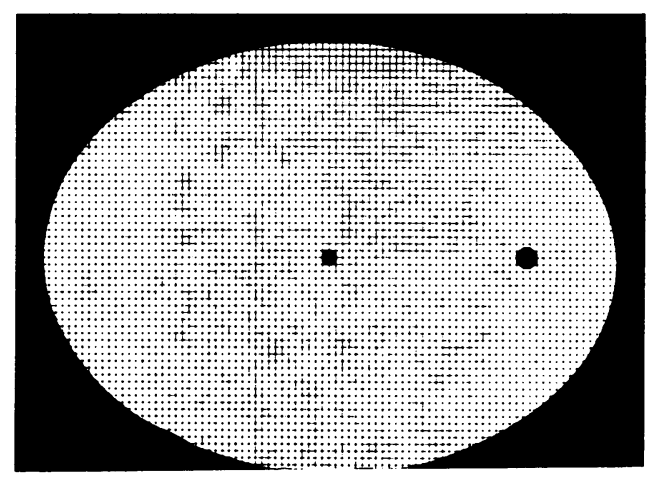

Reading glasses or bifocals were used in all cases where required. When the corrected reading distance was $40 \mathrm{~cm}$. or more a $+0.5 \mathrm{D}$ clip-on was used. A visual acuity of less than N. 10 was considered unacceptable for the trial.

The patient with one eye occluded was seated in front of the chart and asked to move slowly forward, fixing on the red disc, until the black one disappeared; the patient was then instructed to maintain this distance from the chart during the examination. Using a pen as a pointer, blurring over any length of the black elliptical border was then determined and recorded on the chart, when present. The pen was then directed along the vertical lines of the grid within the ellipse, at $2.5 \mathrm{~cm}$. intervals, and any area of obvious blurring or absence of the squares was again recorded on the chart.

As a control, the visual fields were examined previously on the Goldmann Projection Perimeter, but this sequence was changed after Field 10 when the examination with the chart was carried out first. Target sizes used on the Goldmann Projection Perimeter were $\frac{1}{16} \mathrm{~mm}^{2}$ for central fields and $1 \mathrm{~mm} .{ }^{2}$ for the peripheral fields, both without filters. The Goldmann Projection Perimeter 
rather than the Bjerrum Screen, was used as the control, as the distance from the eye to the perimeter is $30 \mathrm{~cm}$., and a light grey background (the background on the chart being cream) is used rather than the black background of the Bjerrum Screen.

\section{Results}

The results, shown in the Table, were taken from an unselected series of patients referred for visual field examination from the Out-Patients Department of Moorfields Eye Hospital, City Road Branch, which included a high preponderance of glaucoma cases. The fields were examined in both eyes, unless the defect was so gross as to affect fixation. Normal fields were not numbered but are indicated by + (i) in the Table of results as and when they were observed in the other eye.

TABLE I

Comparison of Findings in 25 CASES

\begin{tabular}{|c|c|c|c|}
\hline \multirow{2}{*}{$\begin{array}{l}\text { Field } \\
\text { No. }\end{array}$} & \multirow{2}{*}{ Diagnosis } & \multicolumn{2}{|c|}{ Field Loss } \\
\hline & & Goldmann Projection Perimeter & Chart \\
\hline $\begin{array}{l}1 \\
\text { Left eye } \\
+ \text { (i) }\end{array}$ & Not known & $\begin{array}{l}\text { Upper temporal field loss with nasal } \\
\text { extension, extending to } 30^{\circ} \text { isopter }\end{array}$ & $\begin{array}{l}\text { Upper temporal field loss with blurring } \\
\text { of elliptical border from } 8 \text { to } 1 \text { o'clock } \\
\text { position }\end{array}$ \\
\hline Right eye & $\begin{array}{l}\text { Chronic angle-closure } \\
\text { glaucoma }\end{array}$ & No scotoma found & $\begin{array}{l}\text { Dulling of squares } \\
\text { See Discussion }\end{array}$ \\
\hline Left eye & $\begin{array}{l}\text { Chronic angle-closure } \\
\text { glaucoma }\end{array}$ & $\begin{array}{l}\text { Large superior arcuate scotoma extending } \\
\text { to } 30^{\circ} \text { isopter }\end{array}$ & $\begin{array}{l}\text { Superior field loss sparing a small area } \\
\text { above fixation } \\
\text { Blurring of border from } 12 \text { to } 4 \text { o'clock }\end{array}$ \\
\hline $\begin{array}{c}4 \\
\text { Right eye } \\
+ \text { (i) }\end{array}$ & Open-angle glaucoma & $\begin{array}{l}\text { Large superior arcuate scotoma extending } \\
\text { to } 30^{\circ} \text { isopter }\end{array}$ & $\begin{array}{l}\text { Superior field loss } \\
\text { Blurring of border from } 8 \text { to } 3 \text { o'clock }\end{array}$ \\
\hline $\begin{array}{c}5 \\
\text { Right eye }\end{array}$ & $\begin{array}{l}\text { High myopia } \\
\text { Vitreous floaters } \\
\text { ? Glaucoma }\end{array}$ & Generalized field constriction & Generalized field constriction \\
\hline $\begin{array}{c}6 \\
\text { Left eye }\end{array}$ & $\begin{array}{l}\text { High myopia } \\
\text { Vitreous floaters } \\
\text { ? Glaucoma }\end{array}$ & Generalized field constriction & Generalized field constriction \\
\hline $\begin{array}{l}7 \\
\text { Right eye } \\
+ \text { (i) }\end{array}$ & $\begin{array}{l}\text { Chronic angle-closure } \\
\text { glaucoma }\end{array}$ & $\begin{array}{l}\text { Extensive upper field loss extending to } \\
30^{\circ} \text { isopter }\end{array}$ & $\begin{array}{l}\text { Upper field loss, good sparing of squares } \\
\text { above fixation } \\
\text { Blurring of border from } 10 \text { to } 2 \text { o'clock }\end{array}$ \\
\hline $\begin{array}{l}8 \\
\text { Left eye } \\
+(i)\end{array}$ & Open-angle glaucoma & $\begin{array}{l}\text { Extensive superior and inferior arcuate } \\
\text { scotomata } \\
\text { Peripheral field loss inferiorly encroach- } \\
\text { ing into central field }\end{array}$ & $\begin{array}{l}\text { Upper and lower field loss } \\
\text { Blurring of border from } 5 \text { to } 8 \text { o'clock }\end{array}$ \\
\hline $\begin{array}{l}9 \\
\text { Left eye } \\
+ \text { (i) }\end{array}$ & Open-angle glaucoma & $\begin{array}{l}\text { Fixation just present } \\
\text { Small temporal field only } \\
\text { Peripheral field loss encroaching into } \\
\text { central field between } 3 \text { to } 6 \text { o'clock }\end{array}$ & $\begin{array}{l}\text { No squares seen } \\
\text { Border sharp only between } 7 \text { and } 10 \\
\text { o'clock }\end{array}$ \\
\hline $\begin{array}{l}* 10 \\
\text { Right eye } \\
+(\text { i) }\end{array}$ & Retrobulbar neuritis & $\begin{array}{l}\text { Small scotoma below fixation astride } 10^{\circ} \\
\text { isopter }\end{array}$ & Scotoma in similar position \\
\hline $\begin{array}{l}11 \\
\text { Right eye } \\
+ \text { (i) }\end{array}$ & $\begin{array}{l}\text { Retrobulbar neuritis } \\
\text { Fully dilated }\end{array}$ & $\begin{array}{l}\text { Large upper temporal field defect } \\
\text { Small indefinite scotoma separate from } \\
\text { main defect lying between it and } \\
\text { fixation }\end{array}$ & $\begin{array}{l}\text { Loss of square perception in upper } \\
\text { temporal field with slight extension } \\
\text { below the horizontal meridians }\end{array}$ \\
\hline $\begin{array}{l}12 \\
\text { Left eye } \\
+ \text { (i) }\end{array}$ & Open-angle glaucoma & $\begin{array}{l}\text { Inferior arcuate scotoma } \\
\text { Some encroachment of peripheral field } \\
\text { loss into central field }\end{array}$ & $\begin{array}{l}\text { Field loss similar } \\
\text { Blurring of border from } 4 \text { to } 6 \text { o'clock }\end{array}$ \\
\hline $\begin{array}{l}13 \\
\text { Right eye } \\
+(\text { i })\end{array}$ & Open-angle glaucoma & $\begin{array}{l}\text { Extensive inferior arcuate scotoma and } \\
\text { an early superior scotoma }\end{array}$ & $\begin{array}{l}\text { Generalized field loss, more marked } \\
\text { inferiorly }\end{array}$ \\
\hline $\begin{array}{c}14 \\
\text { Right eye }\end{array}$ & $\begin{array}{l}\text { Aphakic glaucoma } \\
\text { Poor witness }\end{array}$ & Extensive superior arcuate scotoma & $\begin{array}{l}\text { Generalized field loss } \\
\text { Blurring of border inferiorly }\end{array}$ \\
\hline
\end{tabular}


TABLE I (continued)

\begin{tabular}{|c|c|c|c|}
\hline \multirow{2}{*}{$\begin{array}{l}\text { Field } \\
\text { No. }\end{array}$} & \multirow{2}{*}{ Diagnosis } & \multicolumn{2}{|c|}{ Field Loss } \\
\hline & & Goldmann Projection Perimeter & Chart \\
\hline $\begin{array}{c}15 \\
\text { Left eye }\end{array}$ & $\begin{array}{l}\text { Aphakic glaucoma } \\
\text { Poor witness }\end{array}$ & Extensive superior arcuate scotoma & $\begin{array}{l}\text { Marked generalized field loss } \\
\text { Blurring of border inferiorly }\end{array}$ \\
\hline $\begin{array}{c}16 \\
\text { Right eye }\end{array}$ & Open-angle glaucoma & $\begin{array}{l}\text { Extensive superior arcuate scotoma } \\
\text { extending to } 30^{\circ} \text { isopter } \\
\text { Peripheral field loss superiorly } \\
\text { Inferior arcuate scotoma }\end{array}$ & $\begin{array}{l}\text { Generalized field loss } \\
\text { Border blurred from } 8 \text { to } 11 \text { o'clock }\end{array}$ \\
\hline $\begin{array}{c}17 \\
\text { Left eye }\end{array}$ & Open-angle glaucoma & $\begin{array}{l}\text { Gross field loss. small central and } \\
\text { temporal areas remaining } \\
\text { Peripheral field loss encroaching on } \\
\text { central field between } 4 \text { and } 6 \text { o'clock }\end{array}$ & $\begin{array}{l}\text { Generalized contraction of field, } \\
\text { remaining field similar in shape to that } \\
\text { on Goldmann Projection Perimeter } \\
\text { Blurring border from } 2 \text { to } 7 \text { o'clock }\end{array}$ \\
\hline $\begin{array}{l}\text { *18 } \\
\text { Right eye } \\
+ \text { (i) }\end{array}$ & $\begin{array}{l}\text { Retrobulbar neuritis } \\
\text { (Same patient as No. } \\
10 \text { but done } 3 \text { weeks } \\
\text { later) }\end{array}$ & $\begin{array}{l}\text { Little change in size or position of } \\
\text { scotoma }\end{array}$ & $\begin{array}{l}\text { Little change in size or position of } \\
\text { scotoma }\end{array}$ \\
\hline $\begin{array}{l}19 \\
\text { Left eye } \\
+(i)\end{array}$ & $\begin{array}{l}\text { Chronic angle-closure } \\
\text { glaucoma }\end{array}$ & $\begin{array}{l}\text { Early superior arcuate scotoma, separate } \\
\text { from blind spot }\end{array}$ & $\begin{array}{l}\text { Field loss in superior temporal region } \\
\text { See Discussion }\end{array}$ \\
\hline $\begin{array}{l}20 \\
\text { Right eye }\end{array}$ & Open-angle glaucoma & Central field full & $\begin{array}{l}\text { Dulling of squares in superior temporal } \\
\text { region } \\
\text { See Discussion }\end{array}$ \\
\hline $\begin{array}{l}21 \\
\text { Right eye }\end{array}$ & Open-angle glaucoma & $\begin{array}{l}\text { Small area of field around fixation, and } \\
\text { separate a small temporal area } \\
\text { Slight encroachment of peripheral field } \\
\text { superiorly }\end{array}$ & $\begin{array}{l}\text { Small area only perceived around } \\
\text { fixation }\end{array}$ \\
\hline$\stackrel{22}{\text { Left eye }}$ & Open-angle glaucoma & $\begin{array}{l}\text { Small area of field around fixation } \\
\text { Slight encroachment of peripheral field } \\
\text { loss superiorly }\end{array}$ & $\begin{array}{l}\text { Small area of field remaining around } \\
\text { fixation }\end{array}$ \\
\hline$\stackrel{* 23}{\text { Right eye }}$ & $\begin{array}{l}\text { Retrobulbar neuritis } \\
\text { (Same patient as Nos. } \\
10 \text { and 18) }\end{array}$ & $\begin{array}{l}\text { Small scotoma astride } 10^{\circ} \text { isopter, below } \\
\text { fixation }\end{array}$ & $\begin{array}{l}\text { Small scotoma astride } 10^{\circ} \text { isopter below } \\
\text { fixation }\end{array}$ \\
\hline $\begin{array}{l}24 \\
\text { Right eye }\end{array}$ & Open-angle glaucoma & $\begin{array}{l}\text { Extensive superior arcuate scotoma, with } \\
\text { some superior field constriction } \\
\text { Constriction of central field inferiorly }\end{array}$ & $\begin{array}{l}\text { Generalized field constriction, more so } \\
\text { superiorly }\end{array}$ \\
\hline $\begin{array}{l}25 \\
\text { Left eye }\end{array}$ & Open-angle glaucoma & $\begin{array}{l}\text { Generalized central field constriction, } \\
\text { especially superiorly }\end{array}$ & $\begin{array}{l}\text { Generalized field constriction, more so } \\
\text { superiorly }\end{array}$ \\
\hline
\end{tabular}

36 eyes were examined, eleven of which were normal on the Goldmann Projection Perimeter and the chart. ${ }^{*}$ Fields 10,18 , and 23 are from the same patient, done at intervals of 3 weeks.

\section{Discussion}

Field examinations were carried out with patients wearing their reading correction, when required; two questions therefore arise:

(1) Will glasses cause distortion of the grid?

(2) Will the near segment of a bifocal have sufficient area to cover the chart without one part being cut-off by the edge of the near segment?

Assuming that the back vertex distance (the distance from the back of the spectacle lens to the cornea) is $12 \mathrm{~mm}$., and that the nodal point of the eye is $7 \mathrm{~mm}$. behind the cornea, the area of the spectacle lens which covers the chart may be calculated from similar triangles. The major axis of the ellipse is $1.4 \mathrm{~cm}$. and the minor axis $1.0 \mathrm{~cm}$. Therefore only a small part of the lens is used and the question of peripheral lens distortion does not arise even in high refractive errors, provided that the patient looks through the optical centre of the spectacle lens. Also the area of the spectacle lens which is covered by the chart lies within the near segment of a bifocal, the diameter of the smallest near segment in normal use being $2.2 \mathrm{~cm}$. Although $+0.5 \mathrm{D}$ clip-ons were used in some cases, useful results may still be obtained without them, though this is slightly more difficult for the patient. 
From the data collected it may be stated that central visual field defects can be found by using static perimetry, and can be shown to cover a similar area when compared with the Goldmann Projection Perimeter. Also some indication can be obtained of peripheral field loss when this is severe enough to encroach into the central visual field. Gross field changes present no problem; it is the early and small scotomata that are readily missed. Three straightforward field defects are illustrated, so that the changes observed on the chart may be compared with those found on the Goldmann Projection Perimeter. In preparing these diagrams adjustments were made so that the two scales were equal.

Field 10 (Fig. 2) illustrates the type of scotoma associated with retrobulbar neuritis. In both the Goldmann Projection Perimeter and the chart, a small scotoma is seen below fixation and astride the $10^{\circ}$ isopter. The patient, an excellent observer, was able to describe subtle changes of the grid within the scotomatous area-an observation which was far more difficult to accomplish on the Goldmann Projection Perimeter. These distortions of the grid are more easily observed when a greater contrast is used, for example black ruling on white paper. No blurring of the black elliptical border was noted.
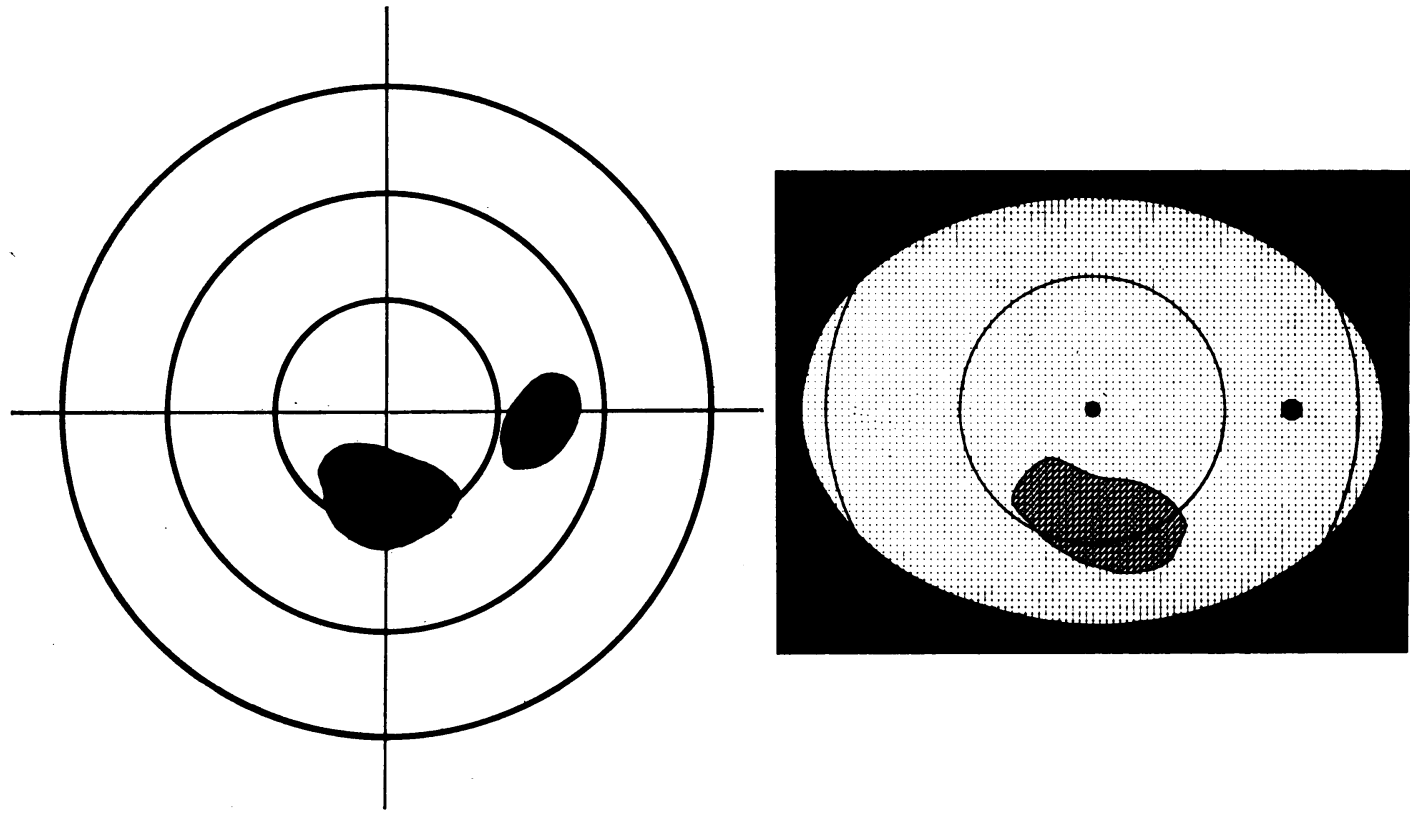

FIG. 2.-Field 10. Retrobulbar neuritis.

(a) The field as plotted on the Goldmann Projection Perimeter, with the $10^{\circ}, 20^{\circ}, 30^{\circ}$ isopters shown. The blind spot and the scotoma are shown in solid black.

(b) The field as plotted on the chart.

For easy comparison with the Goldmann Projection Perimeter the $10^{\circ}$ isopter, and part of the $20^{\circ}$ isopter are shown in Fig. $2 b$ and the following Figures. The area of the scotoma is hatched.

Field 19 (Fig. 3, opposite) shows an early arcuate scotoma occurring in a case of chronic angle-closure glaucoma, the shape and position being typical, when examined on the Goldmann Projection Perimeter. On the chart eccentric blurring of the squares is observed, and there is no loss of sharpness of the black elliptical border, which would appear to indicate that there was no peripheral field loss extending into the central visual field. This was confirmed when the peripheral field was later examined (not shown in Fig. 3). 

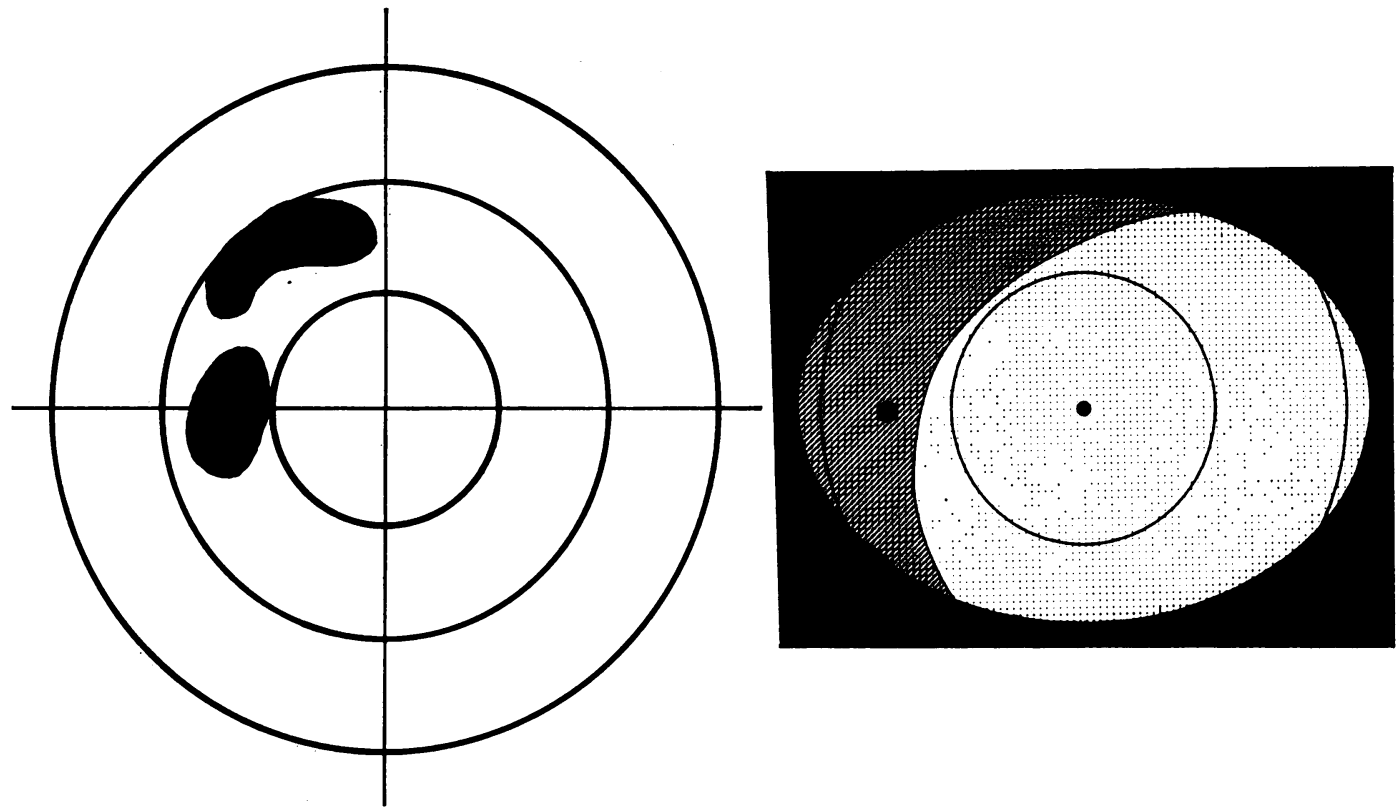

FIG. 3.-Field 19. Chronic angle-closure glaucoma.

(a) Goldmann Projection Perimeter with blind spot and scotoma shown in solid black.

(b) Chart, with area of scotoma hatched.

A more advanced arcuate scotoma (Fig. 4) is seen in Field 12, from a case of open-angle glaucoma. On the Goldmann Projection Perimeter an inferior arcuate scotoma is seen in
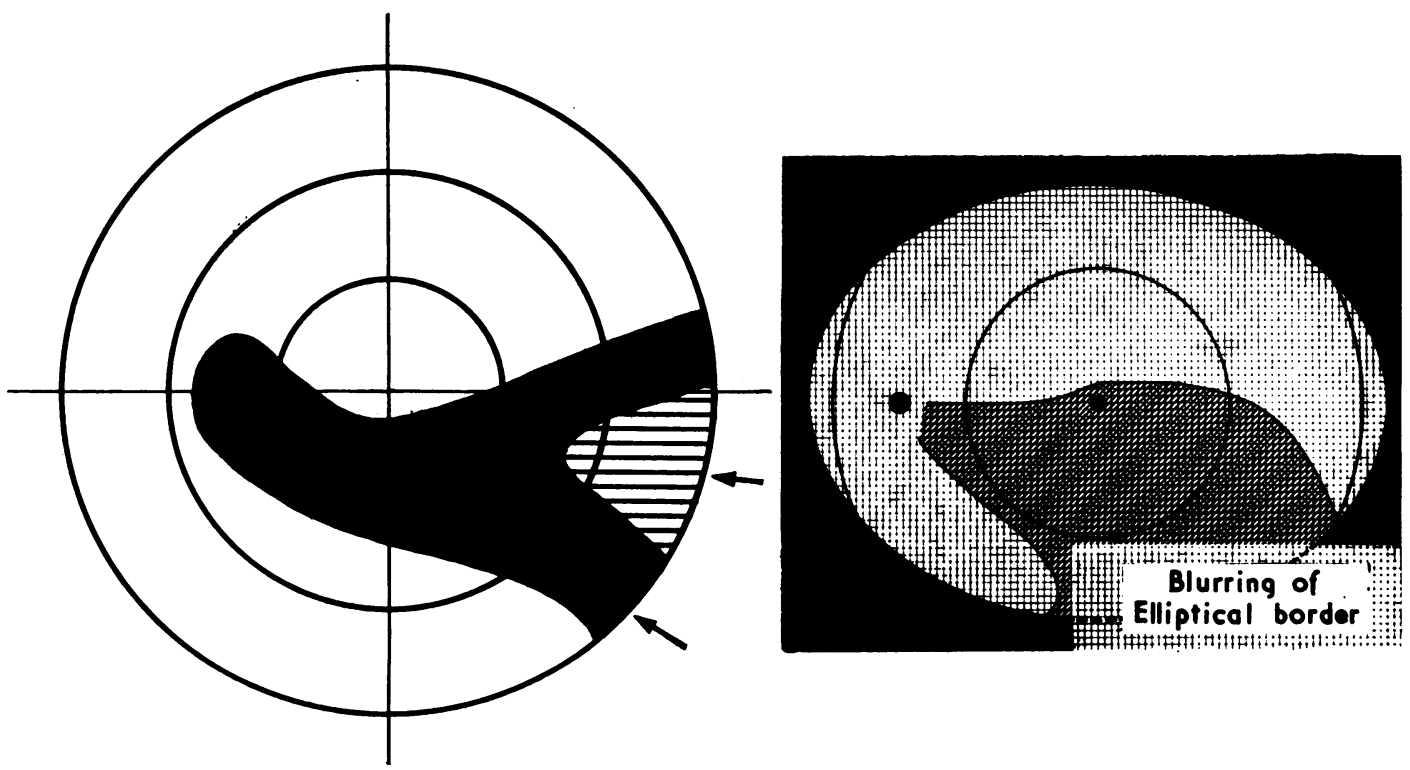

Fig. 4.-Field 12. Open-angle glaucoma.

(a) Goldmann Projection Perimeter; central visual field loss with arcuate scotoma shown in solid black, and peripheral field loss encroaching into the central visual field hatched.

(b) Chart, with area of scotoma hatched. The scotoma extends to the black elliptical border, although it is not shown right to the border for clarity. Note the blurring of the border infra-nasally. 
the central visual field. Peripheral field loss had also occurred with encroachment into the central visual field. On the chart, blurring of the squares demonstrates the presence of this inferior arcuate scotoma; sharpness of the black elliptical border is also seen to be lost over a length which would appear to correspond to the encroachment into the central visual field of peripheral field loss. Slight tilting of the head may explain the different angles of the scotoma as seen in Figs $4 a$ and $4 b$.

The following fields deserve further comment. Field 20 is from the right eye of a patient with bilateral open-angle glaucoma, in whom drainage procedures were carried out in both eyes. The field loss in the left eye was so gross that it did not come within the terms of reference of this series. In the right eye no field loss was demonstrable with the Goldmann Projection Perimeter; but on the chart, in an eccentric area similarly related to the blind spot as shown in Fig. $3 b$, a qualitative difference in the squares was appreciated although they were still recognizable as such.

A similar result is seen in Field 2 from a patient with chronic angle-closure glaucoma. A large superior arcuate scotoma was recorded in the left eye (Field 3), and a full field in the right eye (Field 2) on the Goldmann Projection Perimeter. A corresponding field loss was noted on the chart with the left eye; but with the right eye a qualitative difference (described as dulling) of the grid was observed in the same eccentric manner as in Field 20. It will be of interest to see whether characteristic arcuate scotomata will develop in these eyes.

The following difficulties were encountered. Uncorrected astigmatism, even with a reading visual acuity of $\mathrm{N} 5$, may cause slight doubling of the lines making up the grid and must not be interpreted as a field defect. The exact definition of scotomata with indefinite edges may be difficult for the patient to determine and the observer must then approximate. Care must be taken to differentiate the physiological blurring of the black elliptical border as described in the introduction, and true peripheral field loss encroaching into the central visual field. Blurring of the grid adjacent to the black elliptical border may occur normally, and this effect may be minimized by instructing the patient to close his eyes for a few seconds.

\section{Conclusion}

An investigation was carried out into the use of a suitably designed chart for the plotting of central visual fields at a reading distance. The chart used in this series is simple to use, easy to carry about, and involves no expensive or bulky equipment. The results indicate that scotomata can be found, including the early and the small; there is also some indication of peripheral field loss when this is encroaching into the central visual field. Should further experience confirm these early findings this form of field examination would become a useful additional method in neuro-ophthalmological cases.

I should like to thank Dr. S. Behrman, Mr. J. R. Hudson, Mr. S. J. H. Miller, Mr. H. Ridley, Mr. K. Wybar, Prof. E. S. Perkins, and Dr. R. Weale for their interest, help, and advice, and also Mr. J. H. Redmond Smith for allowing me to use patients referred to the Glaucoma Clinic for field examination.

\section{REFERENCES}

AMSLER, M. (1953). Brit. J. Ophthal., 37, 521.

Williamson-Noble, F. A. (1953). Ibid., 37, 565. 